\title{
Impactos e desafios do uso dos prontuários eletrônicos na prática odontológica - uma revisão de escopo
}

\author{
Impacts and challenges of using electronic records in dental practice - a scoping review \\ Letícia Regina Marques Beserra ${ }^{1}$ \\ Orcid: https://orcid.org/0000-0002-7743-6027 \\ Larianne de Sousa Moisés ${ }^{3}$ \\ Orcid: https://orcid.org/0000-0002-6586-5633 \\ Júlio César Guimarães Freire ${ }^{2}$ \\ Orcid: https://orcid.org/0000-0002-4287-3278 \\ Carmem Silvia Laureano Dalle Piagge ${ }^{4}$ \\ Orcid: https://orcid.org/0000-0001-7999-2943 \\ Cláudia Batista Mélo 5 \\ Orcid: https://orcid.org/0000-0001-5300-3510
}

\begin{abstract}
INTRODUCTION: Paper records are being replaced by electronic dental records for storing personal and clinical data of patients. OBJECTIVE: Through a scoping review, this study aims to investigate the impacts and challenges of using electronic health records in dental practice. MATERIALS AND METHODS: The bibliographic search took place in March 2021, in the Medline/PubMed, LILACS, Scopus, Web of Science databases and, as gray literature, in the first hundred articles searched in Google Scholar. The guiding question of this research, "What are the impacts of using Electronic Health Records in dental practice?", was based on the acronym PCC (Population; Concept; Context) and the PRISMA-ScR guidelines as a reporting guide. The descriptors used were: "Electronic Health Records" and "Dentistry", indexed in the Decs/MeSH platform (Health Sciences Descriptors) and used without time and language restrictions. The Mendeley reference manager was used and, for the selection of studies, the Rayyan software was used. RESULTS: Initially, 3.065 studies were found. After excluding duplicate studies, the selection was performed by reading the titles and abstracts. 32 articles became eligible for whole reading, resulting in 9 studies to compose the sample. CONCLUSION: In the investigation of electronic dental records, it was possible to identify positive impacts, for example, a greater integration of information, which facilitates the analysis of professionals regarding the clinical assessment of patients; better understanding of laboratory and imaging tests; standardization, updating and security of information through digital certification.
\end{abstract}

Keywords: electronic health records; dental records; dentistry.

\begin{abstract}
Resumo
INTRODUÇÃO: Os prontuários em papel estão sendo substituídos pelos prontuários eletrônicos odontológicos para armazenamento dos dados pessoais e clínicos dos pacientes. OBJETIVO: Através de uma revisão de escopo, este estudo tem como objetivo investigar os impactos e desafios do uso de prontuários eletrônicos na prática odontológica. MATERIAIS E MÉTODOS: A pesquisa bibliográfica ocorreu durante o mês março de 2021, nas bases de dados Medline/PubMed, LILACS, Scopus, Web of Science e, como literatura cinzenta, nos cem primeiros artigos pesquisados no Google Scholar. A pergunta norteadora desta pesquisa, “Quais são os impactos na prática odontológica do uso de Prontuários Eletrônicos?”, teve como
\end{abstract}

\footnotetext{
${ }^{1}$ Universidade Federal da Paraíba - UFPB, Brasil. E-mail: leticiareginamb@gmail.com

2 Universidade Federal da Paraíba - UFPB, Brasil. E-mail: juliopb87@gmail.com

${ }^{3}$ Universidade Federal da Paraíba - UFPB, Brasil. E-mail: lariannemoises@hotmail.com

${ }^{4}$ Universidade Federal da Paraíba - UFPB, Brasil. E-mail: carmem.piagge@academico.ufpb.br

${ }^{5}$ Universidade Federal da Paraíba - UFPB, Brasil. E-mail: claudia.melo@academico.ufpb.br
} 
base o acrônimo PCC (População; Conceito; Contexto) e as diretrizes do PRISMA-ScR como guia de relato. Os descritores utilizados foram: "Eletronic Health Records" e "Dentistry", indexados na plataforma Decs/MeSH (Descritores em Ciências da Saúde) e usados sem restrição temporal e de idioma. Foram utilizados o gerenciador de referências Mendeley e, para seleção dos estudos, o software Rayyan. RESULTADOS: Foram encontrados, inicialmente, 3.065 estudos. Após exclusão dos estudos duplicados, foi realizada a seleção por meio da leitura dos títulos e resumos. 32 artigos tornaram-se elegíveis para leitura na íntegra, obtendose 9 estudos para compor a amostra. CONCLUSÃO: Na investigação sobre prontuários eletrônicos odontológicos, foi possível identificar impactos positivos, por exemplo, uma maior integração das informações, que facilita as análises dos profisssionais perante a avaliação clínica dos pacientes; melhor compreensão dos exames laboratoriais e de imagem; padronização, atualização e segurança das informações por meio da certificação digital.

Palavras-chave: registros eletrônicos de saúde; registros odontológicos; odontologia.

\section{Introduction}

The use of technology in the health field has demonstrated an era of information that began with the emergence of electronic records in several countries. The information systems present in the daily lives of professionals have provided support for society in public health activities when analyzed in the context of disease prevention and control, as well as for health promotion, surveillance, and monitoring. The improvement of technologies can benefit the population, such as intensive care for patients with chronic diseases, together with the use of electronic medical records in Primary Health Care (PHC), which allows a continuous interaction between computer systems in the health area $^{1}$.

In this context, ordering documents in a concise manner is the main function of the health record, which has been used in print for a long time, being the only provider of collection and storage of patient information in dental care. This instrument used in the daily life of dentists and other health professionals can evidence and verify the date, diagnosis, treatment plan and procedures performed in the consultations. In addition, the medical record has legal rigor and expertise when used by the professional in the exercise of their profession ${ }^{2}$.

The interdisciplinarity between administration, information technology and health professionals is necessary for the qualification and proper functioning of Electronic Dental Records (EDRs). If this interdisciplinary work does not occur, the probability of mistakes in medical records increases, with wrong or incomplete information and missing documents, generating clinical, legal, and administrative failures ${ }^{3}$. In view of this, the Dental Ethics Code, in item X of article 9, states that the professional has duty to "prepare and keep patient's medical records updated". The use of this resource for maintaining and updating the patient's record cannot be neglected by dentists, as it has a clinical importance, and it can be used in any civil, criminal, and ethical proceedings, in addition to human identification in Forensic Dentistry ${ }^{4}$.

The use of paper-based dental records has disadvantages, such as the difficult handling of storing the material and accessing it later. The EDR becomes a safer option for patient data, having the advantage of storing more information in a small space, making it more practical to carry out procedures that include patient material, allowing remote access at any time and guaranteeing security and confidentiality of patient data ${ }^{5}$. In addition, information on dental care must follow the model proposed by the Federal Council of Dentistry (CFO), as the division into fundamental and supplementary documents ${ }^{6}$.

Due to the spread of Sars-CoV-2 and the emergence of the pandemic of COVID19 , it was possible to observe an increase in the use of technologies in health. In Brazil, for example, Telemedicine was regulated in order to provide remote, elective, and routine care during the pandemic period ${ }^{7}$. Accordingly, the use of computerization in 
the health area is noteworthy, as it allows the exchange of information among professionals; and in Dentistry, it promotes an improvement in the quality of the data collected to improve clinical practice ${ }^{8}$.

In this context, the objective of this study is to present, through a scoping review, the impacts of the use of electronic health records in dental practice, as well as the challenges for the use of this important technological resource by dental surgeons.

\section{Materials and Methods}

This study is a scoping review, a type of methodological approach that synthesizes important information from the health literature, being used to answer questions and assist in practical decisionmaking and in research ${ }^{9}$. As it is a scoping review, there was no submission to the Research Ethics Committee, because it follows the line of thought written in the articles used in the development of this work.

It was registered in an open access repository, the Figshare platform, with the following DOI: https://doi.org/10.6084/m9.figshare.14786 073. In addition, the structural recommendations of the Joanna Briggs Institute were followed, according to the items of the PRISMA-ScR (Preferred Reporting Items for Systematic Reviews and Meta-Analyses extension for Scoping Reviews $)^{10}$. The search was carried out in the following databases: Medline (via PubMed), Scopus, Web of Science, LILACS (Latin American and Caribbean Literature in Health Sciences) and, as grey literature, the first 100 (one hundred) articles made available by Google Scholar were considered. The strategy used was the following: (Electronic Health Record OR Electronic Health Records OR Electronic Medical Record OR Electronic Medical Records OR Computerized Medical Record OR Computerized Medical Records OR (Medical Record AND Electronic) OR (Medical Records AND Electronic) OR (Health Record AND Electronic) OR
(Health Records AND Electronic) OR (Medical Record AND Computerized) OR (Medical Records AND Computerized)) AND (Dentistry).

To construct the article, the following steps were followed: elaboration of the guiding question, definition of the studies to be excluded or included, database search strategy, analysis and synthesis of results to write the text. There was no time or language delimitation.

The guiding question that provided the basis for the development of the review was: "What are the impacts, in the dental practice, of the use of Electronic Health Records?", and to answer it, the items of the acronym PCC were used, in which it is defined: Population(P), Concept(C) and Context $(\mathrm{C})$. The Population is represented by medical records; the Concept is characterized as the investigation, and the Context is the dental context. From each item of the acronym PCC, the keywords and descriptors indexed in DeCS (Health Sciences Descriptors) and MeSH (Medical Subject Headings) were defined, namely: Electronic Records, Electronic Health Records, Odontology and Dentistry.

The aforementioned descriptors were synthesized using the Boolean operators OR and AND, and applied to the indexed databases, including the gray literature, with these combinations being used as search strategies. All records were exported to the Mendeley and Rayyan reference management softwares, and the article selection process was completed in March 2021.

The researchers adopted as inclusion criteria: articles addressing the impacts of the use of electronic health records in dentistry, without restrictions on language and year of publication. As exclusion criteria, the following were considered: book chapters, news, response letters, editorials, dissertations and theses, technical reports, narrative, systematic or integrative literature review studies, research protocols, proceedings of events, 
and articles that did not answer the guiding question.

Data extraction was performed by two researchers independently, who analyzed the studies according to a table built with information such as: title, year, country of study, authors, database, objectives, sample (n) and the main results that answered the guiding question.

\section{Results}

A total of 3.065 studies were found. After removing the duplicates, 3.047 remained. After reading the titles and abstracts, 9 (nine) articles were selected for reading in full. All selected articles highlighted the importance of using electronic dental records, in order to answer the above-mentioned guiding question. The study selection strategy is shown in Figure 1.

Figure 1. Studies selection flowchart for inclusion in the review. Brazil, 2021.

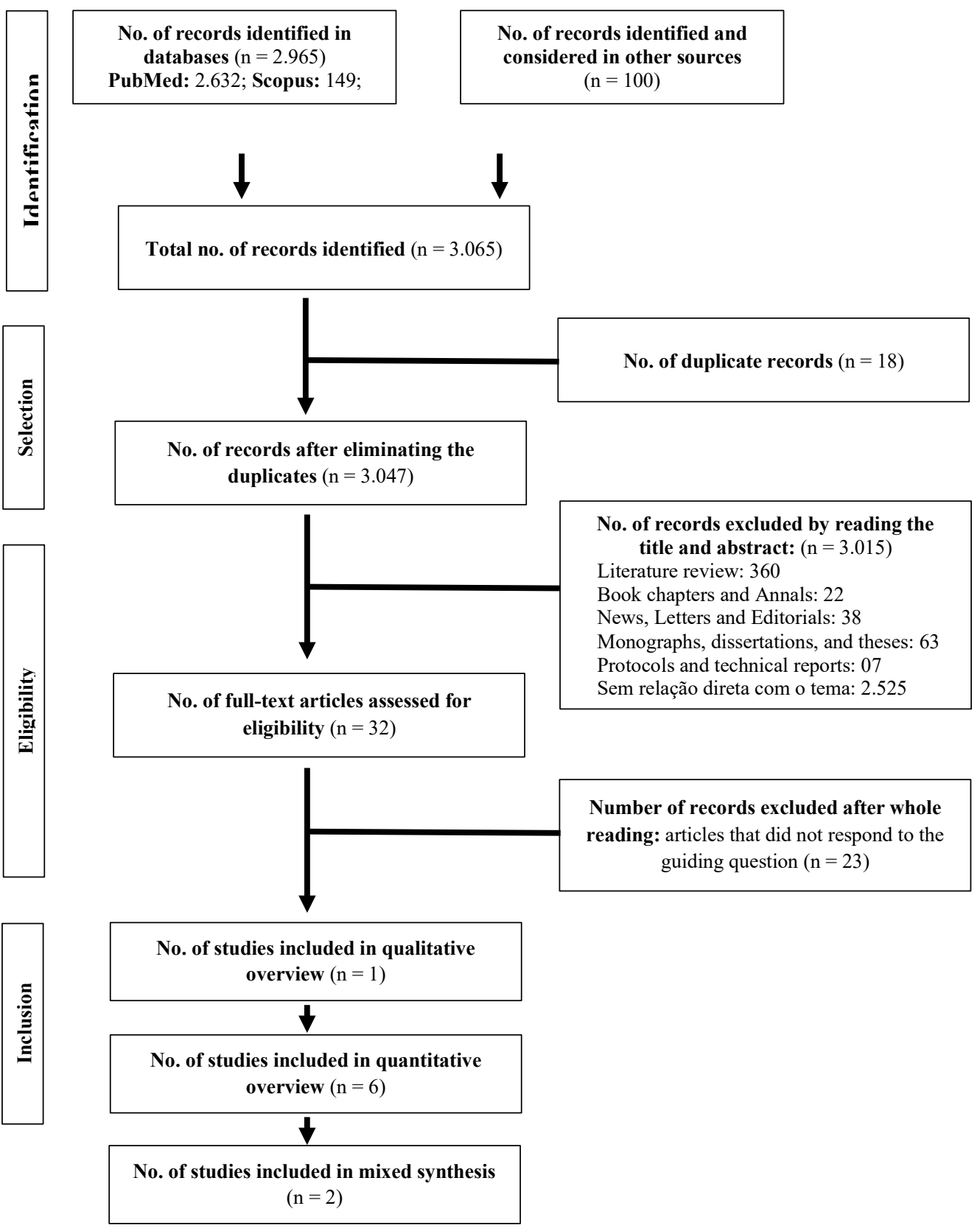

Source: own elaboration. 
The data extracted were organized in a chart containing: author, year, country; title; objective(s); sample (n); conclusion. These, in turn, have mostly the quantitative approach method, showing the data from their analyses. The details of the profile of the included articles are summarized in Chart 1.

Chart 1. Distribution of articles according to author, year, and country of publication; objective(s); sample; conclusion of the study. Brazil, 2021.

\begin{tabular}{|c|c|c|c|c|}
\hline $\begin{array}{c}\text { Author (Year); } \\
\text { Country }\end{array}$ & Title & Objective(s) & $\begin{array}{c}\text { Sample; } \\
\text { Sample size }(n)\end{array}$ & Conclusion \\
\hline $\begin{array}{l}\text { Wagner et al. }{ }^{11} \\
\qquad(2015) \\
\text { Canada }\end{array}$ & $\begin{array}{l}\text { An electronic oral } \\
\text { health record to } \\
\text { document, plan } \\
\text { and educate. }\end{array}$ & $\begin{array}{l}\text { Create an electronic } \\
\text { oral health record } \\
\text { based on the } \\
\text { principles of cognitive } \\
\text { ergonomics to guide } \\
\text { students. }\end{array}$ & $\begin{array}{l}\text { Students, } \\
\text { faculty and staff } \\
\text { of UBC's } \\
\text { Faculty of } \\
\text { Dentistry } \\
(n=485)\end{array}$ & $\begin{array}{l}\text { Improves students' } \\
\text { clinical performance } \\
\text { and the institution's } \\
\text { quality assurance } \\
\text { capacity; facilitates } \\
\text { clinical productivity and } \\
\text { research audits. }\end{array}$ \\
\hline $\begin{array}{c}\text { Thyvalikakath et } \\
\text { al. }^{12}(2020) \\
\text { USA }\end{array}$ & $\begin{array}{c}\text { Leveraging } \\
\text { Electronic Dental } \\
\text { Record Data for } \\
\text { Clinical Research } \\
\text { in the National } \\
\text { Dental PBRN } \\
\text { Practices. }\end{array}$ & $\begin{array}{l}\text { Determine the } \\
\text { feasibility of } \\
\text { conducting clinical } \\
\text { research using } \\
\text { electronic dental } \\
\text { record (EDR) data } \\
\text { from USA general } \\
\text { dental offices. }\end{array}$ & $\begin{array}{c}\text { Electronic } \\
\text { Health Records } \\
\text { (EHR) of } \\
\text { Dentistry } \\
\text { Clinics } \\
(n=99)\end{array}$ & $\begin{array}{l}\text { Allows professionals to } \\
\text { learn about their } \\
\text { patients' outcomes, } \\
\text { using data from their } \\
\text { own practice. }\end{array}$ \\
\hline United Kingdom & $\begin{array}{c}\text { 'Bytes and bites'-- } \\
\text { using } \\
\text { computerized } \\
\text { clinical records to } \\
\text { improve patient } \\
\text { safety in general } \\
\text { dental practice. }\end{array}$ & $\begin{array}{l}\text { Assess the quality of } \\
\text { record keeping of } 134 \\
\text { general dentists } \\
\text { against } 14 \text { Clinical } \\
\text { Governance standards } \\
\text { in the United } \\
\text { Kingdom. }\end{array}$ & $\begin{array}{l}\text { Clinical records } \\
\text { of dentists } \\
\text { contracted } \\
\text { within the scope } \\
\text { of dental } \\
\text { services (NHS) } \\
\qquad(n=134)\end{array}$ & $\begin{array}{l}\text { Computer records were } \\
\text { rated significantly better } \\
\text { than paper records for } \\
11 \text { of the } 14 \text { criteria } \\
\text { evaluated. }\end{array}$ \\
\hline $\begin{array}{l}\text { Simon et al. }{ }^{14} \\
\text { (2019) }\end{array}$ & $\begin{array}{c}\text { Improving Oral- } \\
\text { Systemic } \\
\text { Healthcare } \\
\text { through the } \\
\text { Interoperability of } \\
\text { Electronic } \\
\text { Medical and } \\
\text { Dental Records: } \\
\text { An Exploratory } \\
\text { Study. }\end{array}$ & $\begin{array}{c}\text { Assess current } \\
\text { information sharing } \\
\text { and the value of better } \\
\text { electronic information } \\
\text { sharing. }\end{array}$ & $\begin{array}{l}\text { Physicians and } \\
\text { dentists from } \\
\text { four academic } \\
\text { medical centers } \\
\quad(n=118)\end{array}$ & $\begin{array}{l}\text { An interoperable } \\
\text { Electronic Health } \\
\text { Record would be useful } \\
\text { for practice, but the } \\
\text { desired information was } \\
\text { different among } \\
\text { professionals. }\end{array}$ \\
\hline $\begin{array}{c}\text { Schleyer et al. } \\
\text { (2013) }\end{array}$ & $\begin{array}{l}\text { Electronic dental } \\
\text { record use and } \\
\text { clinical } \\
\text { information } \\
\text { management } \\
\text { patterns among } \\
\text { practitioner- } \\
\text { investigators in } \\
\text { The Dental }\end{array}$ & $\begin{array}{l}\text { Determine what } \\
\text { information } \\
\text { professionals kept on } \\
\text { paper, computer, or } \\
\text { both; and whether } \\
\text { they were willing to } \\
\text { use electronic means } \\
\text { to participate/ } \\
\text { communicate about }\end{array}$ & $\begin{array}{l}\text { North American } \\
\text { and } \\
\text { Scandinavian } \\
\text { professionals- } \\
\text { researchers at } \\
\text { DPBRN } \\
(n=729)\end{array}$ & $\begin{array}{l}\text { Electronic Health } \\
\text { Records can be an } \\
\text { important resource not } \\
\text { only to support clinical } \\
\text { care, but also to support } \\
\text { quality improvement } \\
\text { and research to improve } \\
\text { oral health. }\end{array}$ \\
\hline
\end{tabular}




\begin{tabular}{|c|c|c|c|c|}
\hline & $\begin{array}{c}\text { Practice-Based } \\
\text { Research } \\
\text { Network. }\end{array}$ & $\begin{array}{l}\text { DPBRN research } \\
\text { studies. }\end{array}$ & & \\
\hline $\begin{array}{l}\text { Masoe et al. }{ }^{16} \\
\qquad(2015) \\
\text { Australia }\end{array}$ & $\begin{array}{l}\text { Reliability study } \\
\text { of clinical } \\
\text { electronic records } \\
\text { with paper } \\
\text { records in the } \\
\text { NSW Public Oral } \\
\text { Health Service. }\end{array}$ & $\begin{array}{l}\text { Determine the degree } \\
\text { of concordance } \\
\text { between clinical data } \\
\text { from electronic health } \\
\text { records (EHR) and } \\
\text { paper records. }\end{array}$ & $\begin{array}{l}\text { Electronic } \\
\text { Health Records } \\
\text { from the Public } \\
\text { Oral Health } \\
\text { Service } \\
\text { database and } \\
\text { paper records } \\
\text { from clinics } \\
\qquad(n=400)\end{array}$ & $\begin{array}{l}\text { There were more } \\
\text { deficiencies in paper } \\
\text { records compared to } \\
\text { electronic records. }\end{array}$ \\
\hline $\begin{array}{l}\text { Gordon et al. }{ }^{17} \\
\text { (2018) } \\
\text { USA }\end{array}$ & $\begin{array}{c}\text { Use of the Dental } \\
\text { Electronic Health } \\
\text { Record for } \\
\text { Research: } \\
\text { Assessing } \\
\text { Demographic and } \\
\text { Oral Health } \\
\text { Characteristics } \\
\text { Data for Clinic } \\
\text { Patients. }\end{array}$ & $\begin{array}{l}\text { Analyze demographic } \\
\text { and oral health data in } \\
\text { Electronic Health } \\
\text { Records (EHR) of } \\
\text { eligible patients. }\end{array}$ & $\begin{array}{l}\text { Electronic } \\
\text { Health Records } \\
\text { of the East } \\
\text { Carolina } \\
\text { University } \\
\text { School of } \\
\text { Dental } \\
\text { Medicine ( } n= \\
28.029)\end{array}$ & $\begin{array}{l}\text { The findings illustrate } \\
\text { the potential of using } \\
\text { data collected in EHR } \\
\text { for research studies. }\end{array}$ \\
\hline $\begin{array}{l}\text { Maserat et al. } \\
\qquad(2020)\end{array}$ & $\begin{array}{c}\text { Analysis of } \\
\text { strengths, } \\
\text { weaknesses, } \\
\text { opportunities, and } \\
\text { threats of } \\
\text { electronic dental } \\
\text { and oral records } \\
\text { in clinics of } \\
\text { School of } \\
\text { Dentistry, Tehran } \\
\text { University of } \\
\text { Medical Sciences, } \\
\text { Iran: A qualitative } \\
\text { study. }\end{array}$ & $\begin{array}{l}\text { Analyze the strengths, } \\
\text { weaknesses, the } \\
\text { opportunities, and } \\
\text { threats (SWOT) of } \\
\text { implementing } \\
\text { electronic dental and } \\
\text { oral records. }\end{array}$ & $\begin{array}{l}\text { Clinicians at the } \\
\text { Faculty of } \\
\text { Dentistry, } \\
\text { Tehran } \\
\text { University of } \\
\text { Medical } \\
\text { Sciences, } \\
\text { Tehran, Iran. } \\
(n=15)\end{array}$ & $\begin{array}{l}\text { The use of electronic } \\
\text { dental and oral health } \\
\text { records can help } \\
\text { improve the quality of } \\
\text { information and } \\
\text { ultimately lead to an } \\
\text { improvement in the } \\
\text { quality of care. }\end{array}$ \\
\hline $\begin{array}{c}\text { Langabeer et al. }{ }^{18} \\
(2008)\end{array}$ & $\begin{array}{c}\text { Economic } \\
\text { Outcomes of a } \\
\text { Dental Electronic } \\
\text { Patient Record. }\end{array}$ & $\begin{array}{l}\text { Discover the value of } \\
\text { the electronic system } \\
\text { during the early stages } \\
\text { of the study. }\end{array}$ & $\begin{array}{l}\text { Electronic } \\
\text { health records } \\
(n=1.000)\end{array}$ & $\begin{array}{l}\text { There were positive } \\
\text { economic results from } \\
\text { the electronic patient } \\
\text { record, even considering } \\
\text { the interactive changes } \\
\text { and other risks. }\end{array}$ \\
\hline
\end{tabular}

Source: own elaboration.

The selected studies comprise the time dimension from 2008 to 2020, demonstrating, therefore, to be the most researched topic in the last decade. It was evident that the United States was responsible for $55.5 \%$ of the articles analyzed in full. This fact is linked to the strong tradition and encouragement in research in that country, among other program initiatives for scientific and technological development ${ }^{19}$. 
As for the objectives of the publications to assist in practical decisionmaking and research, these ranged from creating an electronic oral health record; determine the feasibility of conducting clinical research; assess the quality of record keeping and information sharing; determine which patient information the professionals kept on paper, computer or both, in addition to the degree of agreement between clinical data; understand the demographics of oral health and verify the strengths, weaknesses, opportunities and threats (SWOT matrix) of implementing EDRs.

Finally, the study samples involved electronic and clinical records (55.5\%) and health professionals $(44.4 \%)$, and it could be observed that the use of EDRs allowed a better clinical performance of students; professionals learned about their patients' outcomes using data from their own practice; they improved the quality of information and, ultimately, led to an improvement in the quality of care.

\section{Discussion}

The importance of using electronic health records is due to their multiple features, which aim to help professionals in their daily routine in dental offices. Data are analyzed in their entirety to assess the procedures performed, as well as they serve as support for health professionals and researchers to improve the quality of care and for research purposes.

Through the included studies, it was possible to observe that this modernization is already a present reality, as evidenced by the study by Almeida et al. ${ }^{20}$, according to which dental surgeons are following the trend of using technology in the search for an authentic and integral documentation, which allows for the secrecy of information. By comparing the two types of records, the traditional and the technological, it was possible to see that, in relation to agility and quality, the second is the best, as shown by the data from the study by Lopes and
Andrade $^{21}$, which also points out as advantages of using paper records: greater flexibility in handling and transporting them; no training requirement; lack of standardization of handwriting and structure; independence from the internet for its operation.

On the other hand, the disadvantages of using paper-based records include the possibility of losing information, as it exists in only one place; the chance that the handwriting generates dubious interpretations or there is a lack of information, as well as the dependence on a scientific analysis to be carried out only by the professional $^{21}$.

Regarding electronic health records, some positive points are worth mentioning, such as: information security; easier access to the patient's medical history; readable and standardized writing; information system and other integrated bases; greater dexterity in the use of data from imaging and laboratory equipment; update the data. The negative part is the cost of software and hardware, as well as their defects and loss of data, the need for training, time for financial return and the existence of different systems ${ }^{21}$.

The search for a good prognosis leads to the desire for more effective planning, from the moment of the anamnesis, as follows the line of thought by Wagner et al. ${ }^{11}$. This article mentions that the fundamental part of patient care is, in fact, a collection process that encompasses the maximum capacity of information, so that the professional has access to a large amount of clinical data. This can be achieved with the use of electronic patient medical records, as, in addition to storage, it is possible to cross-reference and facilitate access to these records ${ }^{21}$. In addition, the hypothesis that the EDR, together with the use of DDS (Dental Diagnostic System) terminology, leads to the emergence of critical thinking, as it presents a sequence of steps for practice, thus facilitating the use of terms used in dental area ${ }^{22}$. 
According to the results analyzed, more developed countries in terms of technology are those that have the highest frequency of implementation of this reality in their offices and clinics. This is evident in the United States, in view of what Janett and Yeracaris ${ }^{23}$ wrote, who cite them as an example of a region that uses electronic health records through different systems, and clarifies the need for standardization, as this may influence the conduct of the professional before the patient.

In this sense, Dentistry seeks to adapt to the current technological scenario. The increase in work and the use of computers generate the need to use digital documentation to help not only in the personal sphere, but also in the legal sphere. In order to have legal validity, in Brazil, documents available digitally must have a certification with a link to PKI-Brazil (Public Key Infrastructure), as this measure will ensure that the data are secure, authentic and consider privacy, as well as the storage of information in full ${ }^{20}$.

Furthermore, such aspects highlight not only the legal value, but the relevance of the adherence of this type of record to clinical practice, as the replacement of paper-based records for electronic ones would result in the reduction of information divergences, so that it would allow a better accuracy of the clinical records ${ }^{24}$. However, according to Almeida et al. ${ }^{21}$, access to these systems in places such as hospitals occurs equally among professionals, through login and password, which ends up exposing information that should be restricted to certain specialists. Therefore, in order not to expose the patient, health agencies must discuss the limits and propose alternatives for the security of electronic data.

On the national scene, the Certification Manual for Electronic Health Record Systems (S-RES) of the Federal Council of Medicine (CFM) gave rise to this Resolution CFO No. 91/2009, of the Federal Council of Dentistry, which approves the standards techniques concerning digitization, use of computerized systems for the safekeeping and handling of documents in patients' medical records, as to the Security Requirements for Electronic Health Documents. These documents corroborate that electronic record systems must adopt security mechanisms capable of guaranteeing authenticity, confidentiality, and integrity of health information, with digital certification (electronic signature) being the technology that best provides such mechanisms. The SBIS/CFM certification process, for example, is based on national and international standards in Health Informatics, which seek to eliminate system vulnerabilities ${ }^{25}$.

Therefore, based on the sample analyzed, it was possible to ascertain that there are more positive than negative points in the use of electronic records, because, according to Maserat et $\mathrm{al}^{8}{ }^{8}$, they also facilitate the analysis of the patient's dental conditions, helping in the diagnosis of diseases. Therefore, the organization of the structure of the printed medical records makes communication between professionals difficult, as they are organized separately for each area of clinical practice, as well as not being disposed of in the evolutionary path of the disease $\mathrm{d}^{24}$. Furthermore, Pinto and Santos ${ }^{26}$ state that electronic health records generate concise and reliable statistical information to assess the individuality for planning actions for each person or group in need of services.

Digital records are an alternative to the use of paper form, to contribute to reducing the generation of environmental impacts and, therefore, it is suggested, in a future perspective, studies on how beneficial this practice would be for the environment. The existing studies on the subject should be improved so that the subject is always up to date, with a view to collaborating with dental practice.

In short, it was observed that electronic records can operate normally, being quite useful for the clinical practice of health professionals, such as dentists, 
however, sensitive data and clinical information of users need to be safeguarded through systems safe and effective, which continue to be improved in the field of digital health.

\section{Conclusion}

In the investigation of electronic dental records, it was possible to identify positive impacts, such as a greater integration of information, which facilitates the analysis of professionals before the clinical evaluation of patients; better understanding of laboratory tests and imaging, which are stored and can be accessed at any time by the professional; standardization, updating and security of information through digital certification, based on national and international standards in the area of Health Informatics.

The limitations of the study were observed from the results of the literature search, considering that a large part of the universe of articles analyzed concerned literature reviews, which were conducted in the international context. Considering the complexity of the theme addressed and the low number of national publications, it is suggested that primary studies of this nature be carried out in Brazil.

\section{Referências Bibliográficas}

1. Silva, AF, Pauferro, BCS, Cruz, GM, Trezena S, Batista, RWC. O uso das tecnologias de informação e comunicação no ensino e em Odontologia. Revista da AcBO 2019;8(1):33-39.

2. Farias, AC, Filho, CACL, Wanderley, AEC, Bairros, L, Ferreira, SMS. EstomatoPEP: Prontuário eletrônico desenvolvido para otimizar a educação em serviço numa clínica escola de odontologia. Revista Novas Tecnologias na Educação 2019; 17(3):253:262.

3. Costa, SS, Flório, FM. Análise ético-legal de prontuários clínicos de cursos de odontologia brasileiros. Revista Bioética 2020; 28 (3):486-492.

4. Lopes, GC, Andrade, ES. Prontuário Odontológico em Cirurgia Buco-maxilofacial importância clínica, ética e implicações jurídicas: revisão de literatura. Facit Business and Technology Journal 2020; 1(14):87-98.

5. Leite, DRG, Silva, AO, Sampaio, GB, Costa, LJ, Bonan, PRF, Melo, CB. Prontuário eletrônico de estomatologia (PEEST): uma experiência de desenvolvimento e implantação no curso de Odontologia. Revista InterScientia 2018; 6(2):112-123.

6. Barbosa, DV, Nóbrega, WFS, Silva, GCB, Neto, OMM, Feitosa, Prontuário eletrônico do cidadão: aceitação e facilidade de uso pelos cirurgiões-dentistas da atenção básica. Archives of Health Investigation 2020; 9(5):414-419.

7. Brasil. Ministério da Saúde. Portaria $n^{\circ} 467$, de 20 de março de 2020. Dispõe, em caráter excepcional e temporário, sobre as ações de Telemedicina. Diário Oficial da União, Brasília, DF, 2020.

8. Maserat, E, Davoodi, S, Mohammadzadeh, Z. Analysis of strengths, weaknesses, opportunities, and threats of electronic dental and oral records in clinics of School of Dentistry, Tehran University of Medical Sciences, Iran: A qualitative study. Journal of Oral Health and Oral Epidemiology 2020; 9(1):24-31.

9. Tricco, A. C., Lillie, E., Zarin, W., O'Brien, K. K., Colquhoun, H., Levac, D., Moher, D., Peters, M., Horsley, T., Weeks, L., Hempel, S., Akl, E. A., Chang, C., McGowan, 
J. et al. (2018). PRISMA extension for scoping reviews (PRISMA-ScR): checklist and explanation. Annals of Internal Medicine 169(7):467-473.

10. Peters MDJ, Godfrey C, McInerney P, Munn Z, Tricco AC, Khalil H. Chapter 11: Scoping Reviews (2020 version). In: Aromataris E, Munn Z, editors. Joanna Briggs Institute Reviewer's Manual [internet]. JBI, 2020.

11. Wagner, IV, Macneil, MAJL, Esteves, A, MacEntee, MI. An electronic oral health record to document, plan and educate. European Journal of Dental Education 2015; 19:209-216

12. Thyvalikakath, P, Duncan, WD, Siddiqui, Z, Lapradd, M, Eckert, G, Schleyer T, Rindal, D, B, Jurkovich, M, Shea, T, Gilbert, GH. Leveraging Eletronic Dental Record Data for Clinical Research in the National Dental PBRN Practices. Applied Clinical Informatics 2020; 11(2):305-314.

13. Spicer R. 'Bytes and bites' - using computerized clinical records to improve patient safety in general dental practice. Dental Update 2018; 35(9), 614-619.

14. Simon, L, Udoh, EO, Yansane, AI, Gharpure, A, Licht, S, Calvo, J, Deschner, J, Damanaki, A, Hackenberg, Walji, M, Spallek, H, Kalenderian, E. Improving OralSystemic Healthcare through the Interoperability of Electronic Medical and Dental Records: An Exploratory Study. Applied Clinical Informatics 2019; 10(3):367-376.

15. Schleyer, T., Song, M., Gilbert, G. H., Rindal, D. B., Fellows, J. L., Gordan, V. V., \& Funkhouser, E. Electronic dental record use and clinical information management patterns among practitioner-investigators in The Dental Practice-Based Research Network. The Journal of the American Dental Association 2013; 144(1):49-58.

16. Masoe, AV, Blinkhorn, AS, Colyvas, K, Taylor, J, Blinkhorn, FA. Reliability study of clinical electronic records with paper records in the NSW Public Oral Health Service. Public Health Research Practice 2015; 25(2): e2521519.

17. Gordon, SH, Camargo, GA, Mejia, GC, Sutherland, JN. Use of the Dental Electronic Health Record for Research: Assessing Demographic and Oral Health Characteristics Data for Clinic Patients. Journal of Dental Education 2018; 82(12):1249-1257.

18. Langabeer, JR, Walji, MF, Taylor, D, Valenza, A. Economic outcomes of a dental electronic patient record. Journal of Dental Education 2008; 72(10):1189-1200.

19. Alves, Kisna Yasmin Andrade et al. Uso da fotografia nas pesquisas qualitativas da área da saúde: revisão de escopo. Ciência \& Saúde Coletiva 2021; 26(2):521-529.

20. Almeida, SM, Carvalho, SPM, Radicchi, R. Aspectos legais da documentação odontológica: uma revisão sobre validade legal, privacidade e aceitação no meio jurídico. Revista Brasileira de Odontologia Legal 2017; 4(2):55-64.

21. Almeida, MJGG, Figueiredo, BB, Salgado, HC, Torturella, IM. Discussão Ética sobre o Prontuário Eletrônico do Paciente. Revista Brasileira de Educação Médica 2016; 40(3):521-527.

22. Reed, SG, Adibi, SS, Coover, M, Gellin, RG, Wahlquist, AE, AbdulRahiman, A, Hamil, LH, Walji, MF, Neill, PO, Kalenderian, E. Does Use of an Electronic Health Record with Dental Diagnostic System Terminology Promote Dental Students' Critical Thinking? Journal of Dental Education 2015; 79(6):686-696. 
23. Janett, RS, Yeracaris, PP. Electronic Medical Records in the American Health System: challenges and lessons learned. Ciência \& Saúde Coletiva 2020; 25(4):1293-1304.

24. Meneses, LBA, Bezerra, AF, Trajano FMP, Soares, MJG. Revista de Enfermagem UFPE 2015; 9(10):9485-9491.

25. Silva, ML, Virginio Junior, LA. Manual de Certificação para Sistemas de Registro Eletrônico em Saúde - versão 4.2. Conselho Federal de Medicina, Sociedade Brasileira de Informática em Saúde, 2016.

26. Pinto, LF, Santos, LJ. Prontuários eletrônicos na Atenção Primária: gestão de cadastros duplicados e contribuição para estudos epidemiológicos. Ciência \& Saúde Coletiva 2020; 25(4):1305-1312.

\section{How to cite this article:}

Beserra LRM, Freire JCG, Moisés LS, Dalle Piagge CSL, Mélo CB. Impacts and challenges of using Electronic Health Records in dental practice: a scoping review. Rev. Aten. Saúde. 2021; 19(70): 111-121. 